\title{
KEWIRAUSAHAWANAN DAN KARAKTERISTIK INDIVIDU WIRAUSAHA RAMBAK DI DESA BANGSAL MOJOKERTO
}

\author{
Sirot Irjianto \\ PT. MPM Motor Cabang Ngawi Jawa Timur \\ Email: cutex_moxer@yahoo.co.id
}

\begin{abstract}
The research is a survey descriptive research at rambak home-business in Bangsal Village Mojokerto Regency. The first research purpose is finding out entrepreneurship spirit consisted of self confidence, task and result orientation, risk taking, leadership, originality, and orientation for future. Second, to find out individual characteristics consisted of sex, age, business time length, education, and income. Third, is to find out entrepreneurship spirit from individual characteristic in detail. Analytical tools used are scale rank analysis and cross tabulation. The result of research show that the entrepreneurship spirit consist of self confidence, task and result orientation, risk taking, leadership, originality, and orientation for future are carried out in home business. Then, the individual characteristics consist of sex, age, business time length, education, and income.
\end{abstract}

Keywords: entrepreneurship spirit, individual characteristic, home- business

\section{PENDAHULUAN}

Kondisi perekonomian yang memprihatinkan dan konglomerasi yang selama ini diandalkan sebagai tulang punggung pertumbuhan ekonomi nasional, ternyata rapuh dan tidak berdaya dalam menanggulangi krisis ekonomi yang berkepanjangan. Pertumbuhan ekonomi merosot tajam, inflasi melonjak drastis dan kondisi neraca pembayaran internasional memprihatinkan. Konglomerat yang dijadikan tumpuan memacu pertumbuhan ekonomi nasional ternyata tidak mampu memuluskan berfungsinya mekanisme tetesan ke bawah. Hal ini berdampak pada semakin beragamnya jenis pekerjaan yang dipilih oleh setiap orang untuk memenuhi kebutuhan tersebut. Kondisi dan situasi tersebut memunculkan banyak orang untuk membuka usaha sendiri tanpa harus tergantung pada perusahaan atau mencari pekerjaan yang belum pasti, salah satunya adalah bekerja sebagai wirausaha.

Kewirausahaan adalah kemampuan dalam menciptakan sesuatu yang baru dan berbeda (Kasmir, 2006:17). Pengertian ini mengandung maksud bahwa seorang wirausaha adalah orang yang memiliki kemampuan untuk menciptakan sesuatu yang baru, berbeda dengan yang lain. Atau mampu menciptakan sesuatu yang berbeda dengan yang sudah ada sebelumnya. Wirausaha adalah orang-orang yang bertanggung jawab dalam menyusun, mengelola, dan mengukur resiko usaha bisnis (Machfoedz, 2004:1). Wirausaha adalah inovator yang mampu memanfaatkan ide yang dapat dijual atau dipasarkan, memberikan nilai tambah dengan memanfaatkan upaya, waktu, biaya, atau kecakapan dengan tujuan mendapatkan keuntungan.

Jiwa kewirausahawanan adalah salah satu penunjang para pengusaha untuk meraih kesuksesan. Kegagalan atau keberhasilan wirausaha sangat dipengaruhi oleh sifat dan kepribadian seseorang (Suryana,2006:27). Jiwa kewirausahawanan terdiri dari kepercayaan diri, orientasi pada tugas dan hasil, keberanian mengambil resiko, jiwa kepemimpinan, keorisinilan usaha, dan berorientasi ke masa depan (Meredith, 1992:5).

Salah satu bidang usaha yang saat ini banyak ditekuni masyarakat di Bangsal Kecamatan Bangsal Kabupaten Mojokerto adalah usaha rambak. Dimana usaha rambak ini telah menjadi salah satu produk unggulan di Mojokerto. Hal ini tentu saja membuat banyak warga masyarakat yang menekuni usaha rambak ini, yang sampai saat ini sebanyak 63 pengusaha. Usaha rambak ini awal mulanya dirintis oleh Bapak Mahmud dari tahun 1976.

Seiring dengan permintaan masyarakat dan perkembangan usaha yang semakin meningkat maka membawa dampak bagi masyarakat di desa Bangsal Kecamatan Bangsal Kabupaten Mojokerto, 
dalam bisnis rambak ini, tentunya menghadapi berbagai persaingan yang ketat. Hal ini terlihat dari adanya pengusaha-pengusaha baru yang telah mengalami kegagalan, untuk itu dalam menjalankan usaha ini dibutuhkan keseriusan untuk mendapatkan kesuksesan. Kesuksesan wirausaha rambak ini, dapat terlihat dari penghasilan yang dapat digunakan untuk mencukupi kebutuhan sehari-hari, dapat mensejahterakan keluarga dan dapat membuka lapangan pekerjaan bagi masyarakat sekitar.

Para pengusaha rambak ini haruslah memiliki karakteristik wirausaha atau jiwa kewirausahawanan dalam menjalankan usahanya. Sebagaimana halnya yang dilakukan oleh pengusaha rambak di Desa Bangsal ini, untuk dapat memulai usaha rambak ini mereka tentunya memiliki rasa percaya diri dan berani untuk melakukan pengambilan resiko sehingga membuat mereka yakin akan usahanya.

Selain itu dalam pelaksanaannya diperlukan sifat orientasi pada tugas dan hasil sehingga hasil dari produksi nantinya dapat bersaing serta dapat memenuhi target pemasaran. Dalam sektor lain mereka haruslah memiliki jiwa kepemimpinan dalam mengatur karyawannya. Untuk barang produksinya tentunya akan ditentukan dari segi kualitas dan harga sehingga para pengusaha rambak ini akan bersaing dalam hal keorisinilan dimana keorisinilan ini akan membedakan pengusaha yang satu dengan yang lainnya.

Untuk meraih kesuksesan hal yang tidak kalah pentingnya adalah para pengusaha ini harus memiliki orientasi pada masa depan agar nantinya mereka dapat mempertahankan serta mengembangkan usahanya tersebut dalam menghadapi persaingan di masa datang.

Perkembangan jumlah wirausaha rambak yang selalu meningkat tiap tahunnya dapat dilihat dalam beberapa tahun terakhir ini.Berwirausaha seakan menjadi fenomena tersendiri yang masih menyediakan peluang yang sangat terbuka untuk terus dikembangkan. Beragam cara dan kreatifitas dilakukan oleh semua orang dalam berwirausaha. Hal ini karena, dalam berwirausaha setiap orang bebas melakukan apa saja sesuai dengan keinginan masing-masing. Tidak ada batasan-batasan yang menghalangiuntuk terus berkreasi dan berinovasi. Kreasi dan inovasi merupakan hal yang penting, yang harus dilakukan oleh seorang wirausaha. Karena dengan berkreasi dan berinovasi, maka ide akan terus muncul. Menjadi seorang wirausaha merupakan suatu pilihan yang bukan sama sekali tidak ada resiko, karena semua pekerjaan pasti ada resikonya. Oleh karena itu, jiwa kewirausahawanan mempunyai peranan penting yang mendorong para wirausaha untuk mencapai kesuksesan.

Bisnis rambak ini, tentunya menghadapi berbagai persaingan yang ketat. Hal ini terlihat dari adanya pengusaha-pengusaha baru yang telah mengalami kegagalan, untuk itu dalam menjalankan usaha ini dibutuhkan keseriusan untuk mendapatkan kesuksesan.

Tabel 1 Wirausaha Rambak Tahun 2005 - 2010

\begin{tabular}{ccc}
\hline No. & Tahun & Wirausahawan \\
\hline 1 & 2005 & 28 \\
2 & 2006 & 35 \\
3 & 2007 & 38 \\
4 & 2008 & 47 \\
5 & 2009 & 59 \\
6 & 2010 & 63 \\
\hline
\end{tabular}

Sumber: data primer,diolah

Kesuksesan wirausaha rambak ini, dapat terlihat dari penghasilan yang mencukupi, dapat mensejahterakan keluarga dan dapat membuka lapangan pekerjaan bagi masyarakat sekitar. Para pengusaha rambak ini haruslah memiliki karakteristik atau jiwa kewirausahawanan dalam menjalankan usahanya.

Sebagai contoh untuk dapat memulai usaha rambak ini mereka tentunya memiliki rasa percaya diri dan berani untuk melakukan pengambilan risiko, sehingga membuat mereka yakin akan usahanya. Selain itu dalam pelaksanaannya diperlukan sifat orientasi pada tugas dan hasil, sehingga hasil dari produksi nantinya dapat bersaing serta dapat memenuhi target pemasaran.

Dalam sektor lain mereka haruslah memiliki jiwa kepemimpinan dalam mengatur karyawannya. Untuk barang produksinya tentunya akan ditentukan dari segi kualitas dan harga sehingga para pengusaha rambak ini akan bersaing dalam hal keorisinilan, dimana keorisinilan ini akan membedakan pengusaha yang satu dengan yang lainnya. Untuk meraih kesuksesan hal yang tidak penting kalahnya adalah para pengusaha ini harus memiliki orientasi pada masa depan agar nantinya mereka dapat mempertahankan serta mengembangkan usahanya tersebut dalam menghadapi persaingan di masa datang. 
Yohanes Oktavianus dan Tan Tjien Hien (2005) dengan judul "Analisis Karakteristik Wirausaha Dalam Mendorong Kesuksesan Pengrajin Kulit Di Tanggulangin". Tujuan penelitian ini yaitu untuk mengetahui karakteristik pengrajin dan juga untuk mengetahui hubungan antara karakteristik dengan kesuksesan usaha.

Tehnik analisis yang digunakan yaitu dengan menggunakan Analisis Korelasi. Berdasarkan hasil analisis maka dapat diketahui bahwa Karakteristik wirausaha pengrajin yang paling menonjol adalah percaya diri dan yang paling rendah keorisinilan usaha.

Kesuksesan yang paling menonjol dari pengrajin kulit dari pengrajin kulit yaitu kemampuan untuk menjaga kualitas lingkungan dan yang paling rendah perspektif penyediaan lapangan pekerjaan. Hubungan antara karakteristik dengan kesuksesan usaha menunjukkan bahwa variabel orientasi pada masa depan merupakan variabel yang paling kuat dengan kesuksesan usaha.

Fonny Setiawaty dan Maria Fransisca Lenniawaty (2004) dengan judul yang diteliti adalah: "Analisa Karakteristik Wirausahawan dalam Pengembangan Usaha Sendiri di Surabaya Pusat". Tujuan penelitian ini yaitu untuk mengetahui karakteristik wirausaha yang paling dominan yang dibutuhkan dalam berwirausaha.

Teknik analisis data yang digunakan yaitu menggunakan analisis faktor. Berdasarkan hasil analisis maka dapat diketahui bahwa karakteristik wirausaha yang terdiri dari 12 terlihat 4 karakteristik wirausaha yang paling dominan yaitu tanggung jawab, hasrat untuk mendapatkan umpan balik langsung, tingkat energi yang tinggi dan orientasi ke depan.

\section{TINJAUAN PUSTAKA}

Istilah kewirausahaan berasal dari terjemahan "entrepreneurship" yang secara harfiah diterjemahkan sebagai "perantara". Wirausaha sendiri berasal dari kata "entrepreneur" berasal dari bahasa Perancis yang dalam bahasa Inggris berarti "go between" yang artinya "antara" (Alma; 2005: 21). Wirausaha dalam bahasa sansekerta terdiri dari kata wira dan usaha, wira artinya manusia unggul, teladan, bebudi luhur, berjiwa besar, berani, pahlawan/pendekar kemajuan, dan memiliki keagungan watak sedangkan usaha adalah melakukan kegiatan usahaZimmerer dan Scarborough (2008:6) wirausaha adalah seseorang yang menciptakan bisnis baru dengan mengambil resiko dan ketidakpastian demi mencapai keuntungan dan pertumbuhan dengan cara mengidentifikasi berbagai peluang penting dan menggabungkan sumber daya yang diperlukan untuk mengapitalisasikan sumber daya-sumber daya itu adalah sebagai berikut: 1.Karakteristik wirausaha, yaitu Para ahli mengemukakan karakteristik atau jiwa kewirausahawanan dengan konsep yang berbedabeda. Geoffrey G. Meredith (1992: 5) mengemukakan ciri dan watak wirausaha sebagai berikut:

Pengertian dan ciri-ciri kewirausahaan menurut Geoffrey G. Meredith tersebut di jelaskan dalam suryana (2006:39-42) adalah sebagai berikut: 1.Percaya diri, yaitu Kepercayaan diri merupakan suatu paduan sikap dan keyakinan seseorang dalam menghadapi tugas dan pekerjaan (soesarsono Wijandi, 1988). Dalam praktek sikap dan kepercayaan diri ini merupakan sikap dan kepercayaan untuk memulai, melakukan dan menyelesaikan suatu tugas dan pekerjaan yang dihadapi.Oleh karena itu kepercayaan diri memiliki nilai keyakinan, optimisme, individualitas dan ketidak tergantungan.2.Berorientasi tugas dan hasil, yaitu Seseorang yang selalu mengutamakan adalah orang yang selalu mengutamakan nilai-nilai motif prestasi, berorientasi pada laba, ketekunan dan ketabahan, tekad kerja keras, mempunyai dorongan kuat, energik dan berinisiatif.

Keberanian mengambil risiko. Pertama, Keberanian dalam mengambil risiko adalah kemampuan dalam mengambil risiko dan suka pada tantangan. Untuk mencapai kesuksesan dan menghadapi kegagalan, seorang wirausaha harus berani mengambil risiko dan menghadapi segala tantangan.Kedua,. Kepemimpinanadalah suatu sikap yang terlihat dalam diri wirausahawan terhadap pencapaian tugas-tugasnya, dapat bekerja sama dengan orang lain dan mau menerima saran dan kritik dari orang lain.

Ketiga,Keorisinilan terdiri dari kreativitas dan keinofasian. Kreativitas adalah kemampuan untuk berpikir yang baru dan berbeda sedangkan keinofasian adalah kemampuan untuk bertindak yang 
Tabel 2 Karakteristik dan watak kewirausahaan

\begin{tabular}{|c|c|}
\hline Karakteristik & Watak \\
\hline Percaya diri dan optimis & $\begin{array}{l}\text { 1. Memiliki kepercayaan diri yang kuat } \\
\text { 2. Ketidaktergantungan terhadap orang lain } \\
\text { 3. Individualistis }\end{array}$ \\
\hline Berorientasi pada tugas dan hasil & $\begin{array}{l}\text { 1. Kebutuhan untuk berprestasi } \\
\text { 2. Berorientasi laba } \\
\text { Mempunyai dorongan yang kuat, energik } \\
\text { 4. Tekun dan tabah } \\
\text { 5. Tekad kerja keras } \\
\text { 6. Inisiatif }\end{array}$ \\
\hline Berani mengambil resiko dan menyukai tantangan & 1. Mampu mengambil resiko yang wajar \\
\hline Kepemimpinan & $\begin{array}{l}\text { 1. Berjiwa kepemimpinan, } \\
\text { 2. Mudah beradaptasi dengan orang lain } \\
\text { 3. Terbuka terhadap saran dan kritik }\end{array}$ \\
\hline Keorisinilan & $\begin{array}{ll}\text { 1. } & \text { Inovatif } \\
\text { 2. } & \text { Kreatif } \\
\text { 3. } & \text { Fleksibel }\end{array}$ \\
\hline Berorientasi pada masa depan & $\begin{array}{l}\text { 1. Memiliki visi } \\
\text { 2. Perspektif terhadap masa depan. }\end{array}$ \\
\hline
\end{tabular}

baru dan berbeda.Keempat, Berorientasi masa depan Berorientasi kedepan adalah perspektif selalu mencari peluang, tidak cepat puas dengan keberhasilan dan mempunyai pandangan jauh kedepan.

Alasan seseorang menjadi wirausaha Yuyun Wirasasmita dalam Suryana (2006: 55-56) menyatakan sebagai berikut: Pertama, Alasan Keuangan, yaitu mencari nafkah, untuk menjadi kaya, untuk mencari pendapatan tambahan, sebagai jaminan stabilitas keuangan. Kedua, alasan Sosial, yaitu memperoleh gengsi/status, untuk dapat dikenal dan dihormati, utnuk menjadi panutan, agar dapat bertemu dengan orang banyak.

Ketiga, alasan Pelayanan, yaitu memberi pekerjaan kepada masyarakat, membantu anak yatim, membahagiakan orang tua, demi masa depan keluarga, 4. alasan pemenuhan diri, yaitu menjadi atasan/mandiri, untuk mencapai sesuatu yang diinginkan, untuk menghindari ketergantungan pada orang lain, untuk menjadi produktif dan untuk menggunakan kemampuan pribadi.

Beberapa manfaat dan resiko seseorang menjadi wirausaha menurut Zimmerer dan Scarborough (2008:11) adalah sebagai berikut: a. Man- faat berwirausaha, meliputi Pertama,Peluang untuk menentukan nasib sendiri memiliki perusahaan sendiri memberikan kebebasan dan peluang bagi wirausahawan untuk mencapai apa yang penting baginya. Para wirausahawan ingin "mencoba memenangkan" hidup mereka, dan mereka menggunakan bisnis mereka untuk mewujudkan keinginan itu,

Kedua, peluang untuk melakukan perubahan Semakin banyak wirausahawan yang memulai bisnis, karena mereka melihat peluang untuk membuat perubahan yang menurut mereka penting. Misalnya, menyediakan perumahan murah yang layak untuk keluarga dinegara sedang berkembang sperti ini, mendirikan progam daur ulang untuk melestarikan sumber daya bumi yang terbatas,

Ketiga, peluang untuk mencapai potensi sepenuhnya dengan berwirausaha, seseorang dapat memaksimalkan potensi yang ada pada dirinya. Hal ini sangat berbeda dengan seorang pegawai yang pekerjaannya monoton dan merasakan bahwa pekerjaan tersebut sangat membosankan, tidak menantang dan tidak menarik. Bagi seorang wirausaha, tidak banyak berbeda antara bekerja dan bermain, keduanya sama saja, 
Keempat, peluang untuk meraih keuntungan yang menakjubkan. Seorang wirausaha bisa memperoleh keuntungan yang tidak terbatas." orang orang yang bekerja untuk dirinya sendiri memiliki peluang empat kali lebih besar untuk menjadi jutawan daripada orang-orang yang bekerja untuk orang lain", ujar Danko.

Kelima, peluang untuk berperan dalam masyarakat dan mendapatkan pengakuan atas usahanya.Pemilik usaha kecil sering kali merupakan warga masyarakat yang paling dihormati dan paling dipercaya. Kesepakatan bisnis berdasarkan kepercayaan dan saling menghormati adalah ciri perusahaan kecil. Para pemilik usaha mengatakan bahwa hal yang paling dinikmati adalah dapat memberikan kontribusi pada masyarakat setempat.

Keenam, peluang untuk melakukan sesuatu yang disukai dan bersenang-senang dalam mengerjakannya. Wirausahawan yang berhasil memilih masuk dalam bisnis tertentu sebab mereka tertarik dan menyukai pekerjaan tersebut.Mereka membuat hobi mereka menjadi pekerjaan mereka dan senang melakukannya. B. Resiko wirausaha, meliputi, pertama, ketidakpastian pendapatan, yaitu pada masa awal usahanya, pemilik sering kali kesulitan melunasi kewajiban keuangannya karena pendapat yang belum pasti dan mungkin hidup dari tabungan mereka. Pemilik adalah orang terakhir yang menerima gaji,

Kedua, resiko kehilangan seluruh investasi, menjadi seorang wirausaha harus mempunyai kesiapan untuk kehilangan seluruh investasinya, apalagi tingkat kegagalan bisnis kecil relatif sangat tinggi. Ketiga, kerja lama dan kerja keras memulai usaha sering membuat pemilik mengalami mimpi buruk. Sering menghadapi masalah, membutuhkan waktu kerja yang lebih lama, kerja keras dalam bekerja, semua dilakukan agar usaha yang telah dibangun tidak tergeser oleh pesaingnya,

Keempat, kualitas hidup yang rendah sampai hidup mapan.Panjangnya jam kerja dan kerja keras untuk mendirikan usaha akan menyita waktu wirausahawan, hal inimengakibatkan waktu untuk bersama keluarganya menjadi berkurang.Kelima, tingkat stress yang tinggi, memulai dan mengelola perusahaan sendiri dapat menjadi pengalaman yang sangat berharga, dan juga bisa menjadi pengalaman penuh dengan tekanan yang sangat tinggi. Mereka harus bisa mengatasi permasalahan hari-hari penuh dengan kesibukan, memikirkan agar tidak terjadi kegagalan. Hal demikian dapat menimbulkan tingkat stres yang tinggi bagi wirausahawan.

Keenam, tanggung jawab penuh seorang wirausaha harus memiliki tanggung jawab penuh, karena mereka menyadari keputusan yang mereka ambil merupakan penyebab keberhasilan maupun kegagalan. Ketujuh, Keputusasaan dalam menjalankan usahanya seorang wirausaha sering menghadapi hambatan. Ada hambatan yang teratasi dan juga ada yang tidak teratasi. Dalam menghadapi kesulitan seperti itu keputusasaan dan kekecewaan sering dirasakan oleh para pengusaha.

\section{METODE PENELITIAN}

Berdasarkan masalah yang diteliti, peneliti menggolongkan kedalam jenis penelitian survey. Data dikumpulkan dengan melakukan wawancara individu melalui daftar pertanyaan atau kuesioner terstruktur. Dengan survey, periset dapat memperoleh data seperti preferensi, sikap, perasaan atau pengetahuan individu (Istijanto, 2006:43). Dalam penelitian survey, peneliti melakukan pengumpulan data melalui pengamatan dan kuesioner, yang selanjutnya diinterpretasikan dan disimpulkan.

Populasi adalah keseluruhan subyek penelitian, sedangkan sampel adalah sebagian dari wakil populasi yang diteliti Arikunto (2006:131). Adapun populasi dalam penelitian ini adalah seluruh pengusaha rambak di Desa Bangsal Kecamatan Bangsal Kabupaten Mojokerto sebanyak 40 orang. Sedangkan tehnik pengambilan sampel menggunakan tehnik total sampling.

Data primer dalam penelitian ini diperoleh dari penyebaran kuisioner kepada responden tentang karakteristik individu terdiri dari jenis kelamin, usia, pendidikan, lama berwirausaha dan penghasilan. Sedangkan untuk variabel jiwa kewirausahawanan terdiri dari dari kepercayaan diri, orientasi pada tugas dan hasil, keberanian mengambil resiko, jiwa kepemimpinan, keorisinilan usaha, dan berorientasi ke masa depan. Sedangkan, data sekunder berasal dari obyek penelitian yang meliputi jumlah wirausaha rambak di Desa Bangsal, jumlah penduduk dan peta Desa Bangsal. 
Teknik pengumpulan data menggunakan dokumentasi, yaitu mengumpulkan data sekunder dengan cara melihat atau menyalin catatan kertas kerja yang dianggap berhubungan dengan penelitian, yaitu mengenai jumlah pengusaha rambak di daerah Bangsal, jumlah penduduk desa Bangsal. Kuisioner, yakni dengan membagikan angket yang telah disiapkan untuk dijawab oleh responden, dimana angket tersebut berisikan pertanyaan dengan pilihan jawaban yang telah tersusun berdasarkan pilihan dengan cara memberikan tanda pada jawaban yang disediakan.

Variabel dalam penelitian ini terdiri dari variabel bebas X yaitu kewirausahaan, yang didukung oleh beberapa indikator diantaranya X.1 yaitu jiwa kewirausahaan, dibentuk oleh rasa percaya diri, berorientasi pada tugas dan hasil, pengambilan resiko, jiwa kepemimpinan, keorisinilan dan berorientasi masa depan; sedangkan X.2 karakteristik individu dibentuk oleh jenis kelamin, pendidikan, lama berwirausaha, usia dan penghasilan. Pengukuran variabel dilakukan dengan skala Likert. Kategori sangat setuju sama dengan 5, kategori setuju sama dengan 4, kategori ragu-ragu sama dengan 3, kategori tidak setuju sama dengan 2, kategori sangat tidak setuju sama dengan 1.

Untuk memperjelas pengukuran variabel, ada beberapa definisi operasional yang digunakan dalam penelitian ini yang kemudian untuk keperluan analisis secara kuantitatif, maka alternatifjawaban yang digunakan akan diberi score Pertama, jika responden menjawab A (sangat setuju) diberi nilai 4 berarti wirausahawan rambak memiliki jiwa kewirausahawanan sangat tinggi. Kedua,jika responden menjawab B (setuju) diberi nilai 3 berarti wirausahawan rambak memiliki jiwa kewirausahawanan tinggi. Ketiga,jika responden menjawab C (tidak setuju) diberi nilai 2 berarti berarti wirausahawan rambak memiliki jiwa kewirausahawanan rendah. Keempat, jika responden menjawab D (sangat tidak setuju) diberi nilai 1 berarti wirausahawan rambak memiliki jiwa kewirausahawanan sangat rendah.

Pengujian reliabilitas digunakan untuk mengukur kestabilan dan konsistensi responden dalam menjawab hal yang berkaitan dengan daftar pertanyaan yang merupakan dimensi suatu variabel dan disusun dalam suatu bentuk koesioner. Reliabilitas diukur dengan metode konsistensi internal dengan teknik Reliabilitas Alpha, (Arikunto 2006:192). Berdasarkan perhitungan menggunakan alat analisis, variabel jiwa kewirausahaan dinyatakan reliabel dengan nilai 0,8237 . Sedangkan untuk mengetahui rentan skala menggunakan rumus:

$$
\mathrm{RS}=\frac{n(m-1)}{m}
$$

KemudianTabulasi silang (Cross Tabulation) yang merupakan tabel yang mengorganisir data dalam kelompok atau kategori atau kelas yang memungkinkan dilakukannya perbandingannya (Istijianto, 2006: 104). Kelompok atau kategori ini ditampilkan dalam tabel dengan bentuk baris dan kolom.

\section{HASIL DAN PEMBAHASAN}

Jiwa kewirausahawanan para pengusaha rambak di Desa Bangsal Kecamatan Bangsal Kabupaten Mojokerto, dapat dinilai sangat tinggi. Hal ini dapat dilihat dari skor rata - rata variabel jiwa kewirausahawanan sebesar 130 yang berada pada rentang skala sangat tinggi. Hal ini dapat dibuktikan dari tingginya rasa percaya diri yang dimiliki dari pengusaha dalam menjalankan usahanya, sangat tingginya sikap berorientasi pada tugas dan hasil, tingginya keberanian pengusaha dalam mengambil resiko, sangat jiwa kepemimpinan yang dimiliki, sangat tingginya keorisinilan dalam usahanya, serta sangat tingginya keinginan untuk memikirkan usahanya pada masa yang akan datang. Hal ini menunjukkan bahwa dalam menjalankan usahanya ini dibutuhkan jiwa kewirausahawanan yang nantinya bisa mendukung kesuksesannya.

Karakteristik individu berdasarkan jenis kelamin yang dimiliki oleh pengusaha rambak, keseluruhannya adalah laki - laki atau 40 orang. Berdasarkan usia, mayoritas pengusaha berusia 31 sampai dengan 40 tahun sebanyak 17 orang. Berdasarkan lama berwirausaha, mayoritas pengusaha sudah menjalankan usahanya lebih dari 10 tahun sebanyak 20 orang. Berdasarkan 
pendidikan, mayoritas pengusaha memiliki pendidikan SMA sebanyak 19 orang.

Berdasarkan penghasilan, mayoritas pengusaha berpenghasilan 5 sampai 8 juta setiap bulannya. Jiwa kewirausahawanan ditinjau dari karakteristik individu pengusaha rambak. Bahwa seluruhnya berjenis kelamin laki-laki yaitu sebanyak 40 orang atau $100 \%$, sedangkan dari jenis kelamin laki-laki ini yang memilki jiwa kewirausahawanan dengan kategori sangat tinggi sebanyak 27 orang atau $67,5 \%$.

Berdasarkan usia mayoritas individu yang memiliki jiwa kewirausahawanan sangat tinggi pada usia 30 sampai 40 dan usia lebih dari 40 tahun sebanyak 22 orang atau 55\%. Jika dilihat dari tingkat lama berwirausaha, bahwa mayoritas pengusaha yang memilikijiwa kewirausahawanan sangat tinggi yakni pengusaha yang sudah menjalankan usahanya lebih dari 10 tahun sebanyak 14 orang atau 35\%.

Jika dilihat dari tingkat pendidikan yang dimiliki oleh responden, mayoritas responden memilikijiwa kewirausahawanan kategori sangat tinggi yakni kelompok individu dengan pendidikan SMA sebanyak 12 orang atau $30 \%$. Jika dilihat dari tingkat penghasilan yang diperoleh, bahwa mayoritas individu yang memilikijiwa kewirausahawanan dengan kategori sangat tinggi yakni individu yang berpenghasilan 5 sampai 8 juta perbulannya sebanyak 13 orang atau $32.5 \%$.

Hasil tabulasi silang antara karakteristik individu dengan jiwa kewirausahawanan dengan kategori sangat tinggi dapat dilihat pada tabel berikut:

Tabel 4. Hasil Tabulasi Silang

\begin{tabular}{|c|c|c|}
\hline \multicolumn{2}{|c|}{ Karakteristik Individu } & \multirow{2}{*}{$\begin{array}{c}\text { Jiwa } \\
\text { Kewirausahawanan }\end{array}$} \\
\hline Macam Karakteristik & Jumlah & \\
\hline $\begin{array}{l}\text { Jenis Kelamin } \\
\text { Laki-laki }\end{array}$ & 27 & Sangat Tinggi \\
\hline $\begin{array}{l}\text { Usia } \\
30-40 \text { dan }>40 \text { tahun }\end{array}$ & 22 & Sangat Tinggi \\
\hline $\begin{array}{l}\text { Lama Berwirausaha } \\
>10 \text { tahun }\end{array}$ & 14 & Sangat Tinggi \\
\hline $\begin{array}{l}\text { Pendidikan } \\
\text { SMA }\end{array}$ & 12 & Sangat Tinggi \\
\hline $\begin{array}{l}\text { Penghasilan } \\
5-8 \text { juta }\end{array}$ & 13 & Sangat Tinggi \\
\hline
\end{tabular}

Berdasarkan tabel diatas dapat dinyatakan bahwa karakteristik atau jiwa kewirausahawanan sangatlah penting dimiliki oleh pengusaha dalam menjalankan usahanya. Semakin tinggi karakteristik wirausaha yang dimiliki akan semakin menunjang keberhasilannya. Hal ini, sesuai dengan teori yang di paparkan oleh Suryana (2006) yang menyatakan bahwa kegagalan atau keberhasilan wirausaha sangat dipengaruhi oleh sifat dan kepribadian seseorang.

Yuyun wirasasmita (1994:2) dalam Suryana menyatakan bahwa wirausaha yang sukses adalah wirausaha yang mandiri dan percaya diri. Teori karakteristik wirausaha yang telah di paparkan diatas sesuai dengan teori yang dikemukakan oleh Lonngenecker, Moore dan Petty (2001) yang menyatakan bahwa karakteristik wirausaha terdiri dari kebutuhan akan keberhasilan, keinginan untuk mengambil resiko, percaya diri, keinginan yang kuat dalam berbisnis.

\section{SIMPULAN}

Setelah dilakukan penelitian tentang analisis deskriptif karakteristik wirausaha pada pengusaha rambak dapat disimpulkan bahwahasil perhitungan rentang skala karakteristik wirausaha terhadap pengusaha rambak sebesar 130 yang berarti sangat tinggi. Hal ini menunjukkan bahwa karakteristik wirausaha pada pengusaha rambak bisa dikatakan baik.

Jika dilihat dari indikator menyukai tantangan seharusnya responden harus lebih menyukai tantangan, akan tetapi harus diperhitungkan terlebih dahulu resiko yang nantinya akan di hadapi. Oleh sebab itu, perlu dilakukan penelitian lebihmendalam dan luas kaitannya dengan jiwa kewirausahawanan. Dalam hal ini khususnya, mencari pengaruh jiwa kewirausahawanan dalam mendorong kesuksesan usaha sehingga dapat diketahui apakah karakteristik wirausaha memiliki pengaruh dalam mendorong kesuksesan usaha.

\section{DAFTAR PUSTAKA}

Arikunto, Suharsimi, 2006. Prosedur Penelitian Suatu Pendekatan Praktik. Edisi Revisi VI.PT. Cetakan Ketigabelas. Rineka Cipta. Jakarta. 
As'ad. 2003. Seri Ilmu dan Sumber Daya Manusia: Psikologi Industri dan Organisasi. Yogyakarta: Liberty

Istijanto. 2006. Riset Sumber Daya Manusia. Cetakan kedua. PT. Gramedia Pustaka Utama. Jakarta

Meredith, Geoffrey G.1992. Kewirausahaan Teori dan Praktek.PT Pustaka Binaman Pressindo. Jakarta Pusat.

Sugiyono, 2001. Metode Penelitian Administrasi. CV. Alfabeta. Bandung.

Suryana. 2006.Kewirausahaan. Salemba Empat. Jakarta.

Machfoedz. 2004. Kewirausahaan Suatu Pendekatan Kontemporer. UPP.AMP YKPN. Yoykarta.

Kasmir. 2006. Kewirausahaan. PT Rajagrafindo Persada. Jakarta
Longecker, Justin G.,Carlos W. Moore, J. William Petty.2001. Kewirausahaan Manajemen Usaha Kecil. Salaemba Empat.Jakarta.

Umar, Husein.2004.Riset Sumber Daya Manusia Dalam Organisasi. PT. Gramedia Pustaka Utama. Jakarta.

Wiratmo, Masykur.1996. Pengantar Kewirausahaan: Kerangka Dasar Memasuki Dunia Bisnis. BPFE. Yogyakarta. Yohanes Oktavianus dan Tan Tjien Hien. 2005. Analisis Karakteristik Wirausaha Dalam Mendorong Kesuksesan Pengrajin Kulit Di Tanggulangin. Universitas Petra Surabaya

Zimmerer, T.W.,Scarborough N.M (Edisi Bahasa Indonesia).2008. Kewirausahaan dan Manajemen Usaha Kecil. Salemba Empat. Jakarta. 